\title{
Journal of Brand Management: year end review 2018
}

\author{
Shaun M. Powell ${ }^{1}$
}

Published online: 1 October 2018

(c) Springer Nature Limited 2018

\begin{abstract}
This is a review and reflection of various Special Issue themes published in the Journal of Brand Management during 2018. Future research avenues are also identified. Themes discussed include (1) Brands that do Good, (2) Internal Brand Management and (3) Luxury BrandBuilding.
\end{abstract}

Keywords Brand citizenship - Social brand equity · Brand authenticity - Social responsibility - CSR - Sustainability · City branding - Internal brand management - Employees . Brand orientation - Luxury branding · Conspicuous consumption $\cdot$ Social media $\cdot$ Research directions

\section{Introduction}

Currently celebrating its 25th year of production, the Journal of Brand Management (JBM) continues to consider all dimensions of this fast-evolving field, drawing together cutting-edge analysis and some of the latest thinking from leading International experts in academia and industry. As Volume 25 draws to a close and following reviews in previous years (Powell 2015, 2016, 2017), this article reflects upon several timely Special Issue themes published during 2018. Future challenges and research avenues are also delineated. The Special Issue themes include: (1) Brands that do Good, (2) Internal Brand Management and (3) Luxury Brand-Building. Many

Shaun M. Powell

spowell@uow.edu.au

1 School of Management, Operations and Marketing, Faculty of Business, University of Wollongong, Northfields Ave, Wollongong, NSW 2522, Australia additional thought-provoking topics have also been published and discussed throughout the year as outlined in Table 1.

\section{Special Issue 1: Brands that do Good}

Volume 25 launched with a stimulating Special Issue (SI) Guest Edited by Stuart Roper, Ming Lim and Oriol Iglesias. The SI is linked to the 11th Global Brand Conference of the Academy of Marketing's Special Interest Group in Brand, Identity and Corporate Reputation, hosted by the University of Bradford School of Management. The SI theme encompasses how sustainability challenges are challenging the fields of corporate branding, corporate reputation and identity management. Papers within the SI present new insights into the contributions of brands to society, communities and other stakeholders (Roper et al. 2018).

The first original article by Naidoo and Abratt (2018) considers 'social brand equity', arguing that the social sector consists of additional complexities not experienced by the commercial sector. Hence, determining the value of social brand equity may be different to commercial brand equity. Social brands for the study are defined as brands 'representing a cluster of functional, emotional and behavioural benefits that support a social issue' (Naidoo and Abratt 2018, p. 3). Exploratory qualitative research is undertaken with experts across four continents. The article first considers existing models of brand equity from various perspectives to help underpin the comparative study, including that of social marketing. Findings indicate social brand equity has different meanings according to type of stakeholder. Also a number of meaningful differences are identified when compared to commercial brand equity. No 
Table 1 Additional original articles and commentaries published within JBM Volume 25 (2018)

\begin{tabular}{|c|c|c|c|}
\hline $\begin{array}{l}\text { The impact of linguistic proximity } \\
\text { and diglossia on brand name and } \\
\text { slogan extension tendencies in } \\
\text { the Turkish, Russian and Arabic } \\
\text { contexts (Kadirov et al. 2018) }\end{array}$ & $\begin{array}{l}\text { An experiment on non-luxury } \\
\text { fashion counterfeit purchase: } \\
\text { the effects of brand reputation, } \\
\text { fashion attributes, and } \\
\text { attitudes toward counterfeiting } \\
\text { (Park-Poaps and Kang 2018) }\end{array}$ & $\begin{array}{l}\text { The power of experiential } \\
\text { marketing: exploring the causal } \\
\text { relationships among } \\
\text { multisensory marketing, brand } \\
\text { experience, customer perceived } \\
\text { value and brand strength } \\
\text { (Wiedmann et al. 2018) }\end{array}$ & $\begin{array}{l}\text { How reading in a foreign versus } \\
\text { native language moderates the } \\
\text { impact of repetition-induced } \\
\text { brand placement prominence on } \\
\text { placement responses } \\
\text { (Avramova et al. 2018) }\end{array}$ \\
\hline $\begin{array}{l}\text { Modeling brand immunity: the } \\
\text { moderating role of generational } \\
\text { cohort membership (Saju et al. } \\
\text { 2018) }\end{array}$ & $\begin{array}{l}\text { Power relations within brand } \\
\text { management: the challenge of } \\
\text { social media (Leitch and } \\
\text { Merlot 2018) }\end{array}$ & $\begin{array}{l}\text { The boundaries for ad creativity: } \\
\text { effects of type of divergence and } \\
\text { brand processing and responses } \\
\text { (Chen and Smith 2018) }\end{array}$ & $\begin{array}{l}\text { Brands using historical } \\
\text { references: a consumers' } \\
\text { perspective (Pecot and De } \\
\text { Barnier 2018) }\end{array}$ \\
\hline $\begin{array}{l}\text { Using time in branding: reflections } \\
\text { and orientations in an } \\
\text { increasingly competitive world } \\
\text { (Davies 2018) }\end{array}$ & $\begin{array}{l}\text { Antecedents and consequences } \\
\text { of participation in brand } \\
\text { communities: a literature } \\
\text { review (Hook et al. 2018) }\end{array}$ & $\begin{array}{l}\text { Explaining brand switching } \\
\text { behavior using pull-push- } \\
\text { mooring theory and the theory of } \\
\text { reasoned action (Kordi } \\
\text { Ghasrodashti 2018) }\end{array}$ & $\begin{array}{l}\text { Does the type of attribute matter? } \\
\text { Examining whether underlying } \\
\text { factors explain product attribute } \\
\text { preference (Wilkie et al. 2018) }\end{array}$ \\
\hline $\begin{array}{l}\text { Does brand authenticity alleviate } \\
\text { the effect of brand scandals? } \\
\text { (Guèvremont and Grohmann } \\
\text { 2018) }\end{array}$ & $\begin{array}{l}\text { Luxury brands do not glitter } \\
\text { equally for everyone (Aliyev } \\
\text { et al. 2018) }\end{array}$ & $\begin{array}{l}\text { Transforming history into heritage: } \\
\text { applying corporate heritage to the } \\
\text { marketing of places (Wilson } \\
\text { 2018) }\end{array}$ & $\begin{array}{l}20 \text { Years of brand personality: a } \\
\text { bibliometric review and } \\
\text { research agenda (Radler 2018) }\end{array}$ \\
\hline $\begin{array}{l}\text { Roses are red, violets are blue, } \\
\text { sophisticated brands have a } \\
\text { Tiffany Hue: the effect of iconic } \\
\text { brand color priming on brand } \\
\text { personality judgments (Baxter } \\
\text { et al. 2018) }\end{array}$ & $\begin{array}{l}\text { Taking a deliberate approach: } \\
\text { the enactment of brand } \\
\text { orientation in an SME context } \\
\text { (Hodge et al. 2018) }\end{array}$ & $\begin{array}{l}\text { Examining the meanings and } \\
\text { consumption of sport licensed } \\
\text { products through team } \\
\text { identification (Apostolopoulou } \\
\text { and Papadimitriou 2018) }\end{array}$ & $\begin{array}{l}\text { The influence of perceived } \\
\text { strength of brand origin on } \\
\text { willingness to pay more for } \\
\text { luxury goods (Siew et al. 2018) }\end{array}$ \\
\hline $\begin{array}{l}\text { The brand experience extended } \\
\text { model: a meta-analysis (de } \\
\text { Oliveira Santini et al. 2018) }\end{array}$ & $\begin{array}{l}\text { Trajectories of brand hate } \\
\text { (Zarantonello et al. 2018) }\end{array}$ & $\begin{array}{l}\text { Consumer responses to brand } \\
\text { deletion (Mishra 2018) }\end{array}$ & $\begin{array}{l}\text { In search of tools for the use of } \\
\text { country image (CI) in the brand } \\
\text { (Suter et al. 2018) }\end{array}$ \\
\hline $\begin{array}{l}\text { Brand fidelity: a relationship } \\
\text { maintenance perspective (Grace } \\
\text { et al. 2018) }\end{array}$ & & & \\
\hline
\end{tabular}

significant differences in responses were noted between countries/regions included in the study. While the study acts as a foundation, the authors suggest further research with larger and more diverse populations, to add depth and insights into the means of valuing and measuring social brand equity and ultimately to develop a social brand equity model.

The second article by Merrilees et al. (2018), undertakes a quantitative study on Hong Kong, while highlighting previous research including within the CSR and branding domains, has tended to focus on "creating a "good" brand rather than how the brand can contribute or "do good", (Merrilees et al. 2018, p. 15). Acknowledging the nexus discussed earlier within JBM by Powell (2016) and others between corporate branding and city branding, the study considers various branding, city branding, culture plus heritage perspectives. The findings provide a number of practical and theoretical implications, including the proposition of a three-layer representation of the structure of city brand meaning in the context of Hong Kong. Future research is suggested to test the models applicability for other cities in Asia. City brand scholars are also more widely encouraged to re-examine city brands via a combined culture and city brand meaning lens.

The third article by Johnson et al. (2018) undertakes an exploratory study investigating how socially responsible companies (reflecting a brand's commitment to activities related to societal issues for enhancing social good) are valued by consumers, in comparison with competent companies (with ability associations, relating to brand's commitment to creating and delivering high-quality products). Findings indicate the importance of differing consumption goals that should be taken into account, particularly when considering 'experiential consumption'. A number of important practical implications are also outlined. Future research is called for in real-world contexts plus to examine how differing brand associations and consumption goals may aid or detract from a firms' initiatives, including communication strategies based on social responsibility. Research should also investigate the potential moderating impact of risk and other product characteristics. 
The fourth article by Pritchard and Wilson (2018) sets out to examine consumer response to a green new product (GNP), in this case a new wind farm for an energy service company, and their impact on a parent firm's corporate reputation. The research discusses prior research on consumer reactions to products, companies and CSR initiatives and the relevance and importance of moderators. To enhance generalisations of the research, the authors conclude by calling for a wider range of enquiry within other industries and use of alternative research designs.

The fifth article by Samuel et al. (2018) investigates the authenticity gap within socially responsible initiatives via a case study focused on a campaign by Levi's, based on research via focus groups with expert practitioners. The findings identify eight factors to consider. Further research is proposed to consider the findings in the context of smaller less established brands. Additionally, consideration of the role of social geography and the notion of place with regards CSR authenticity is also advised.

Rounding off the Special Issue, Yoganathan et al. (2018) consider the inherent tension for brands that do good when faced also with a need to improve commercial competitiveness. Among other aspects, their research considers the hierarchy of core values in relation to a corporate brand and proposes a basis for management of the paradox due to brand evolution. The outcome is the development of a useful visual compass that may be applied to aid evaluation of core corporate brand values. Moving forward, replication of the research is suggested within alternative organisational contexts and across differing industries, while also considering both hard and soft metrics in the evaluation of 'brands that do good'.

\section{Special Issue 2: Internal Brand Management}

The second of the Special Issues Guest Edited by Rico Piehler, Debra Grace and Christoph Burmann, tackles the challenging theme of Internal Brand Management (IBM). The editors also usefully scope out future research required in the area including (1) further validation of the relevance of IBM, (2) increasing the generalisability of IBM research findings, (3) deepening and (4) broadening the IBM framework and (5) an extension of methodologies in the area (Piehler et al. 2018).

The first original article in the SI considers the organisational antecedents and consequences of internal branding in relation to brand orientation, strategic brand management, plus brand performance (Iyer et al. 2018). Results bring into focus the key mediating role internal branding plays in relation to brand performance. From a theoretical perspective, the research indicates internal branding can increase employee loyalty to an organisation, which may in turn reduce employee turnover. Future research avenues include the need to take account of environmental factors, as well as inclusion of larger more generalisable samples for testing their research model. Longitudinal research is also suggested, as is further exploration of the role of internal branding in managing the continuity/change paradox often noted in brand management.

The second article by Piehler (2018) investigates employee brand understanding and brand commitment in relation to brand citizenship behaviour within a German tourism company. The results build upon prior research in the area, offering various theoretical contributions. For managers the research affirms the importance of 'brand understanding' as a cognitive antecedent and 'brand commitment' as an affective antecedent for brand citizenship behaviour. Future research is suggested to consider potential moderator variables, including personal variables such as employee age and education, plus organisational factors such as resources available and the work environment. Additional research avenues are also sketched out.

The third article considers brand signalling as an antecedent of employee brand understanding (Karanges et al. 2018), with a brand signalling model developed. The model considers brand signal quality, brand signaller quality and brand signal channel quality, in relation to employee brand understanding. Future research is encouraged to provide guidance for managers on how to provide clear, credible and consistent communications to employees. Research is also needed to identify why some employees may still misinterpret the brand promise being communicated. The relevance and impact of additional noise which may be present in the brand signalling hierarchy is another avenue for research.

The fourth article sets out to consider the success factors for internally oriented brand ambassador programs (Schmidt and Baumgarth 2018). A framework containing 25 success factors across six categories is developed, based on prior research and findings from a longitudinal case study. The findings outline a number of important practical implications for managers, including some areas where conflict may occur within a brand ambassador program. Further research is required to uncover the most relevant factors to focus upon. Research may also be extended to additional regions, industries and sectors, as well as across organisations with differing corporate cultures, organisational structures, and/or differing internal branding activities.

The concluding article in the Special Issue by Hofer and Grohs (2018) unpacks the role of a firm's sponsorships directed and communicated externally to consumers, in relation to also achieving internal branding goals. The study focuses on how employees' perceptions of sponsorship characteristics impact their own identification with the 
brand. The findings suggest that where external communication activities are designed adequately, they may be deemed relevant for both external and internal audiences. Future research avenues include exploring additional industries as well as differing kinds of sponsorship in relation to internal brand identification. Research is also needed on strategies for encouraging employees to become involved in a firm's sponsorship activities.

\section{Special Issue 3: Luxury brand-building}

The third special issue Guest Edited by Michel Gutsatz and Klaus Heine insightfully explores new challenges and trends in luxury brand-building and development, highlighting 'the luxury segment is facing tremendous changes and challenges that call for new strategies and entirely new business models' (Gutsatz and Heine 2018a, p. 409).

Based on the literature and case study data analysis, the first original article in the SI considers 'is luxury expensive or has it really been democratized?' (Gutsatz and Heine 2018b, p. 411). The findings present implications for luxury brand managers and researchers relating to the measurement and evolution of prices. Various future research avenues are delineated by the authors including expanding the research to additional countries, as well as extending the study to 'company-internal data about price-related business and branding strategies' (Gutsatz and Heine 2018b, p. 421).

The second article by Kapferer and Valette-Florence (2018) considers the impact of increased brand penetration on luxury desirability, where 'more desire creates more sales, but more sales can hurt desirability' (Kapferer and Valette-Florence, p. 424). Among other aspects, the research highlights for luxury growth a balance is required between inclusion and exclusion which needs to be considered carefully. Moving forward, the authors suggest research could investigate less mature countries than those used in their study, as well as studies that take an experience or service dominant perspective.

Highlighting the lack of research on the topic, the third article undertakes a study of brand discourses for seven luxury brands in order to consider the cross-gender extension potential of luxury brands (Veg-Sala and Roux 2018). The semiotic methodology utilised indicates not all brands are able to legitimately undertake cross-gender extensions. The findings present various important theoretical and managerial implications. The authors also propose future research in the luxury market might like to consider service brands and high-technology brands.

Pointing out that marketers of luxury brands have increasingly embraced the use of social media to convey their brands to consumers, the fourth article by Lee et al.
(2018) considers visual communication of luxury fashion brands on social media. The findings highlight a difference between levels of complexity that should be used in visual images on social media for well-known brands, compared to brands that are new or unfamiliar to consumers. The study provides an underpinning for further research on the influence of visual content on social media for consumers, and their behaviour regarding luxury products.

The fifth article by Depeyre et al. (2018), based upon five cases of brand-building by suppliers of luxury brands, explores 'coopetition' in the French luxury industry. Five triggers leading to coopetition are discussed along with various examples, plus a deeper focus is provided on suppliers who decide to move down the value chain. Future research is suggested to explore cases in additional markets, including emerging markets.

The concluding article in the Special Issue by Heine et al. (2018) combines the concepts of brand personality and brand anthropomorphisation and introduces the notion of 'personality-driven luxury brand management'. Findings outline the major dimensions of luxury brand personality as a tool for building brand personality. A number of important lessons learned are also delineated and discussed for managers.

\section{Conclusion}

The Special Issues above alongside the other articles published in Volume 25 (see Table 1) provide some of the latest thinking in the field of Brand Management. Moving forward, the Journal Editors continue to encourage submission of original and insightful articles as well as industry-based case studies which rigorously consider:

1. models and theories effectively used in brand management research and practice

2. how the world's leading companies are managing their brands

3. the latest thinking, techniques and initiatives used by agencies and consultants

4. current case studies which explore leading organisations' practical experiences, the problems faced and the lessons learned, and

5. applied research from leading business schools, research institutes and universities.

Acknowledgements The author would like to thank fellow JBM coeditor Joachim Kernstock for his joint stewardship of Volume 25. The JBM Editors would also like to thank all Special Issue guest editors, many peer reviewers as well as submitting authors, plus the staff of the publishing team at Palgrave Macmillan and Springer Nature for their support of the journal throughout 2018. 


\section{References}

Aliyev, F., T. Ürkmez, and R. Wagner. 2018. Luxury brands do not glitter equally for everyone. Journal of Brand Management 25(4): 337-350.

Apostolopoulou, A., and D. Papadimitriou. 2018. Examining the meanings and consumption of sport licensed products through team identification. Journal of Brand Management. https://doi. org/10.1057/s41262-018-0102-8.

Avramova, Y.R., P. De Pelsmacker, and N. Dens. 2018. How reading in a foreign versus native language moderates the impact of repetition-induced brand placement prominence on placement responses. Journal of Brand Management. https://doi.org/10. 1057/s41262-018-0103-7.

Balmer, J.M.T., S.M. Powell, J. Kernstock, and T.O. Brexendorf. 2017. Advances in Corporate Branding. Journal of Brand Management: Advanced Collections Series. London: Palgrave Macmillan.

Baxter, S.M., J. Ilicic, and A. Kulczynski. 2018. Roses are red, violets are blue, sophisticated brands have a Tiffany Hue: The effect of iconic brand color priming on brand personality judgments. Journal of Brand Management 25(4): 384-394.

Chen, J., and R.E. Smith. 2018. The boundaries for ad creativity: Effects of type of divergence and brand processing and responses. Journal of Brand Management. https://doi.org/10. 1057/s41262-018-0106-4.

Davies, M.A.P. 2018. Using time in branding: Reflections and orientations in an increasingly competitive world. Journal of Brand Management 25(2): 93-100.

de Oliveira Santini, F., W.J. Ladeira, C.H. Sampaio, and D.C. Pinto. 2018. The brand experience extended model: A meta-analysis. Journal of Brand Management. https://doi.org/10.1057/s41262018-0104-6.

Depeyre, C., E. Rigaud, and F. Seraidarian. 2018. Coopetition in the French luxury industry: Five cases of brand-building by suppliers of luxury brands. Journal of Brand Management 25(5): 463-473.

Grace, D., M. Ross, and C. King. 2018. Brand fidelity: A relationship maintenance perspective. Journal of Brand Management. https:// doi.org/10.1057/s41262-018-0127-z.

Gutsatz, M., and K. Heine. 2018a. Luxury brand-building and development: New global challenges, new business models. Journal of Brand Management 25(5): 409-410.

Gutsatz, M., and K. Heine. 2018b. Is luxury expensive? Journal of Brand Management 25(5): 411-423.

Guèvremont, A., and B. Grohmann. 2018. Does brand authenticity alleviate the effect of brand scandals? Journal of Brand Management 25(4): 322-336.

Heine, K., G. Atwal, S. Crener-Ricard, and M. Phan. 2018. Personality-driven luxury brand management. Journal of Brand Management 25(5): 474-487.

Hodge, N.M., C. McMullen, and J. Kleinschafer. 2018. Taking a deliberate approach: The enactment of brand orientation in an SME context. Journal of Brand Management 25(4): 395-408.

Hofer, K.M., and R. Grohs. 2018. Sponsorship as an internal branding tool and its effects on employees' identification with the brand. Journal of Brand Management 25(3): 266-275.

Hook, M., S. Baxter, and A. Kulczynski. 2018. Antecedents and consequences of participation in brand communities: A literature review. Journal of Brand Management 25(4): 277-292.

Iyer, P., A. Davari, and A. Paswan. 2018. Determinants of brand performance: The role of internal branding. Journal of Brand Management 25(3): 202-216.
Johnson, Z.S., Y.J. Lee, and M.T. Ashoori. 2018. Brand associations: The value of ability versus social responsibility depends on consumer goals. Journal of Brand Management 25(1): 27-37.

Kadirov, D., A. Bardakc1, and M. Kantar. 2018. The impact of linguistic proximity and diglossia on brand name and slogan extension tendencies in the Turkish, Russian and Arabic contexts. Journal of Brand Management 25(2): 147-159.

Kapferer, J.N.M., and P. Valette-Florence. 2018. The impact of increased brand penetration on luxury desirability: A dual effect. Journal of Brand Management 25(5): 424-435.

Kapferer, JN., J. Kernstock, T.O. Brexendorf., and S.M. Powell. 2017. Advances in Luxury Brand Management. Journal of Brand Management: Advanced Collections Series. London: Palgrave Macmillan.

Karanges, E., K.A. Johnston, I. Lings, and A.T. Beatson. 2018. Brand signalling: An antecedent of employee brand understanding. Journal of Brand Management 25(3): 235-249.

Kordi Ghasrodashti, E. 2018. Explaining brand switching behavior using pull-push-mooring theory and the theory of reasoned action. Journal of Brand Management 25(4): 293-304.

Lee, J.E., S. Hur, and B. Watkins. 2018. Visual communication of luxury fashion brands on social media: Effects of visual complexity and brand familiarity. Journal of Brand Management 25(5): 449-462.

Leitch, S., and E. Merlot. 2018. Power relations within brand management: The challenge of social media. Journal of Brand Management 25(2): 85-92.

Merrilees, B., D. Miller, G.L. Ge, and C.C.C. Tam. 2018. Asian city brand meaning: A Hong Kong perspective. Journal of Brand Management 25(1): 14-26.

Mishra, A.A. 2018. Consumer responses to brand deletion. Journal of Brand Management 25(2): 160-170.

Naidoo, C., and R. Abratt. 2018. Brands that do good: Insight into social brand equity. Journal of Brand Management 25(1): 3-13.

Park-Poaps, H., and J. Kang. 2018. An experiment on non-luxury fashion counterfeit purchase: The effects of brand reputation, fashion attributes, and attitudes toward counterfeiting. Journal of Brand Management 25(2): 185-196.

Pecot, F., and V. De Barnier. 2018. Brands using historical references: A consumers' perspective. Journal of Brand Management 25(2): 171-184.

Piehler, R. 2018. Employees' brand understanding, brand commitment, and brand citizenship behaviour: A closer look at the relationships among construct dimensions. Journal of Brand Management 25(3): 217-234.

Piehler, R., D. Grace, and C. Burmann. 2018. Internal brand management: Introduction to the special issue and directions for future research. Journal of Brand Management 25(3): 197-201.

Powell, S.M. 2015. Journal of Brand Management-Year end review 2015. Journal of Brand Management 22(9): 715-720.

Powell, S.M. 2016. Journal of Brand Management-Year end review 2016. Journal of Brand Management 23(6): 601-611.

Powell, S.M. 2017. Journal of Brand Management-Year end review 2017. Journal of Brand Management 24(6): 509-515.

Pritchard, M., and T. Wilson. 2018. Building corporate reputation through consumer responses to green new products. Journal of Brand Management 25(1): 38-52.

Radler, V.M. 2018. 20 Years of brand personality: A bibliometric review and research agenda. Journal of Brand Management 25(4): 370-383.

Roper, S., M. Lim, and O. Iglesias. 2018. 'Brands that do Good' (11th global brand conference), University of Bradford School of Management. Journal of Brand Management 25(1): 1-2. 
Saju, B., K. Harikrishnan, and S. Joseph Jeya Anand. 2018. Modeling brand immunity: The moderating role of generational cohort membership. Journal of Brand Management 25(2): 133-146.

Samuel, A., D. Taylor, G.R.T. White, and M. Norris. 2018. Unpacking the authenticity gap in corporate social responsibility: Lessons learned from Levi's 'Go Forth Braddock' campaign. Journal of Brand Management 25(1): 53-67.

Schmidt, H.J., and C. Baumgarth. 2018. Strengthening internal brand equity with brand ambassador programs: Development and testing of a success factor model. Journal of Brand Management 25(3): 250-265.

Siew, S.W., M.S. Minor, and R. Felix. 2018. The influence of perceived strength of brand origin on willingness to pay more for luxury goods. Journal of Brand Management. https://doi.org/10. 1057/s41262-018-0114-4.

Suter, M.B., J. de Moura Engracia Giraldi, F.M. Borini, M.L. Ferranty MacLennan, E. Crescitelli, and E. Fernandes Polo. 2018. In search of tools for the use of country image (CI) in the brand. Journal of Brand Management 25(2): 119-132.

Veg-Sala, N., and E. Roux. 2018. Cross-gender extension potential of luxury brands: A semiotic analysis. Journal of Brand Management 25(5): 436-448.

Wiedmann, K.P., F. Labenz, J. Haase, and N. Hennigs. 2018. The power of experiential marketing: Exploring the causal relationships among multisensory marketing, brand experience, customer perceived value and brand strength. Journal of Brand Management 25(2): 101-118.

Wilkie, D.C.H., L.W. Johnson, and W.W. Chin. 2018. Does the type of attribute matter? Examining whether underlying factors explain product attribute preference. Journal of Brand Management 25(4): 305-321.

Wilson, R.T. 2018. Transforming history into heritage: Applying corporate heritage to the marketing of places. Journal of Brand Management 25(4): 351-369.

Yoganathan, V., F. McLeay, V.S. Osburg, and D. Hart. 2018. The Core Value Compass: Visually evaluating the goodness of brands that do good. Journal of Brand Management 25(1): 68-83.

Zarantonello, L., S. Romani, S. Grappi, and M. Fetscherin. 2018. Trajectories of brand hate. Journal of Brand Management. https://doi.org/10.1057/s41262-018-0105-5.

Shaun M. Powell has been co-editor of the Journal of Brand Management since 2012. His research has been published in various International refereed journals and books. Recent co-edited books include 'Advances in Luxury Brand Management' (Kapferer et al. 2017) and 'Advances in Corporate Branding' (Balmer et al. 2017) published by Palgrave Macmillan. He regularly presents at international academic, practitioner and industry-based summits, conferences and symposiums in his areas of expertise and interest. 